\title{
THE LOCAL AUTHORITY ENGINEER AND HIGH
}

\section{EARTHQUAKE RISK BUILDINGS}

\section{A. N. Grigg*}

In the 1942 Wairarapa earthquake, many commercial buildings in the Wellington region were damaged. One particular building in Lower Hutt in the main shopping area is of interest, as the action taken by the Lower Hutt City Council contributed towards the amended legislation that is being discussed at this seminar.

Basically, this two-storey building was constructed of unreinforced masonry party and longitudinal dividing walls, with timber first floor and light timber frame roof. The wall fronting the street was of timber frame. After the 1942 earthquake, some of the damaged areas were taken down but the remaining parts were in somewhat doubtful state of security in the minds of the Council. At this time the building was under the control of Trustees and, in the early 1950s, some further portions of the building were taken down and other parts further secured. The property then changed ownership. The new owner, Ernest Leighton Ltd., was advised of the continuing state of weakness of the building prior to purchasing it and in general terms accepted that the building would have to come down.

Also about this time (1955), the Emergency Regulations which came into force after the 1942 earthquake, were repealed so that Council's powers to take further action were restricted to Section 300 of the Municipal Corporations Act, 1954. The building continued to settle and generally deteriorate and, in 1960, a final notice was served on the owner to demolish the building within three months.

As the owner did not comply with the notice of demolition, the matter was heard in the Magistrate's Court in August, 1961. In addition to the detailed evidence produced by Council's officers, a consulting engineer was commissioned by Council to report independently on this hazardous building. In his decision, Mr. J. R. Drummond, S. M., pointed out that the respondent did not seriously challenge the risk associated with the occurrence of a major earthquake.

Mr. Drummond referred to the legal argument by the counsel as to the need for the Earthquake Damage Emergency Regulations 1942 if there was sufficient power under Section 300 of the Municipal Corporations Act as this case was being taken under that section. He also drew the distinction between "a source of public danger" and "may become a source of public danger in the event of an earthquake." The application for demolition was declined and the case dismissed.

\footnotetext{
* City Engineer, Lower Hutt.
}

The Lower Hutt City Council decided to appeal against this decision and there was some delay and doubt as to whether there was any right of appeal. However, the case was heard in the supreme Court in February, 1964 , by Mr. Justice Hutchison who ruled that this section of the Act covered present dangers and those foreseeable in the future, such as the result of progressive deterioration due to weather, usage, traffic vibrations, or the like. On the question of a major earthquake, the learned judge ruled that this did not come within this section of the Act as it is unpredictable whether such an earthquake would come within a given time or even whether it would come at all. The appeal was dismissed.

My Council advised the Minister of Internal Affairs of the decision and the appeal, and requested action by means of amending legislation as this test case highlighted the lack of powers for local authorities to take action in case of high earthquake risk buildings.

In the Gisborne earthquake of 1966 , a number of buildings were damaged and surveys were carried out on the damage by various interested organisations. One such organisation was the Ministry of Works and a full report was presented. The publicity from this earthquake resulted in the long awaited amending legislation on high earthquake risk buildings, being gazetted in 1968.

The new Section 301A as written has several important and unusual features:-

(I) A Local Authority must apply to the Minister for an order in Council prior to having the right to exercise power under this part of the Act. This seems a rather unusual requirement but it could be a restrictive clause to ensure that local authorities so authorised have suitable engineering staff to thoroughly evaluate a building and to safeguard the owner against unreasonable use of power.

(2) The Council, having obtained authority to use this section of the Act, has a discretionary power. The Act says that the Council, on being satisfied that a building is an earthquake hazard, may require the owner to strengthen or demolish the building as the council sees fit. This section differs from the section of the same Act covering fire protection whereby Councils are required to adopt and enforce certain By-Laws. On other aspects of public safety such as licensing of boarding houses, apartment buildings, and places of assembly, Council is required to take positive action. 
(3) The scope of the Act is also restrictive as it applies only to buildings constructed wholly or substantially of unreinforced concrete or unreinforced masonry. The structural engineer can see other buildings outside this scope that could be as hazardous as those covered. This is another means taken by Government to restrict Local Authorities in their powers. Provided Government uses the present Act as the first stage of an overall plan for removing these hazards, there would be only minor objections.

(4) The Local Authority has the right to determine whether a building should be demolished or strengthened. When the law was first published, this point was not clear and it could be interpreted that the option lay with the owner but the matter has been clarified by the 1971 amendment.

(5) Once the local authority has served a notice on the owner to strengthen or demolish a high earthquake risk building, the owner may apply to the court for the case to be heard. Provision is made in the legislation for two assessors to assist the court. These assessors are persons of special skill and knowledge and are appointed by the Minister.

(6) A right of appeal to the supreme court is provided.

The local authority now having been granted the power to take action in the case of high earthquake risk buildings has to decide on what way it will undertake the responsibility. If it accepts this

responsibility, its programme must be logical and reasonable. In order to achieve these objectives a survey of all buildings within the Authority's area is required and some criteria must be laid down to assess the worst hazards and to evaluate the life of others.

The present code on Classification of High Earthquake Risk Buildings provides the local authority with this necessary means of evaluation. It takes into account the use to which a building is put. Buildings such as places of assembly and those that house essential services in an emergency are of more importance to the community than buildings used as offices, factories, etc. The risk of a large number of people's lives being endangered is so much greater.

Evaluation of complex matters is best handled by means of a classification system with demerit points. The system has a wide application and is used in traffic engineering to establish orders of priority: it has been introduced by the Ministry of Works to evaluate the effect of a project on the environment: and it has now been used by the Ministry of Works for a number of years in assessing earthquake risk buildings. In determining fire premiums, insurance companies use a form of classification by assessing the risk after consideration of a number of factors relating to the particular building.

The present system being studied today sets out five criteria, each of which has penalty points ranging from zero to three. It is possible that the number of criteria. could be increased but it is considered that the main points are covered and any increase would complicate the issue without corresponding benefit. A paper presented to an Earthquake Symposium in 1961 advocated ten criteria.

The proposed system relies upon a survey of all structures that are within the scope of the legislation and applying demerit or penalty points according to the degrees of non-compliance. This is basically a visual inspection of the structure after the plans of the original building have been examined. From the total of the penalty points for a particular building and its occupancy, the life evaluation can be assessed from Table 2.

It can be appreciated that the number of buildings coming within the terms of the legislation and the number within the various groups of life evaluation will vary from city to city. Provision is made in the code for a local authority to introduce a factor $\mathrm{K}$ into the life evaluation so that the overall picture within that area can be taken into account.

It should be emphasized that this then sets the priorities so that the buildings of greatest risk to numbers of people come to the top of the list. This is the first stage that a local authority should undertake. The process of inspection is laid down in the code and, if undertaken by one experienced person with local knowledge, a consistent result should be obtained.

Once the order of priorities has been set, the second stage involves the determination of the actual strength of the buildings. Those buildings at the top of the priority list should be examined first. This involves a structural check on the building, consideration of dead and live loads, and seismic analysis. The seismic forces to be used are half those specified in the 1965 edition of Chapter 8, N.Z.S. 1900, at the date of the legislation. It is presumed that amendments to Chapter 8 passed subsequent to the date of the legislation would not apply. The exercise of a structural analysis under the required loading is a valid approach and is a reversal of the normal design procedures. By applying the horizontal and vertical loads mathematically to the building, the overall stability of the structure as well as the level of stress on the various components can be determined. The Local Authority should take reasonable care in evaluating the strength of the structure, but responsibility of producing detailed evidence is the owner's, should he wish to contest any order served on him under section $301 \mathrm{~A}$ of the Act.

One difficulty may arise in obtaining adequate plans of the building as most of the high earthquake risk buildings were erected prior to 1935. The ultimate strength capacity of the structure is to be determined and some difficulties in this area are envisaged, but some guidance is given in the code. If the ultimate 
strength of the building is exceeded by the seismic requirement as calculated above, the local authority can proceed with a notice to the owner to strengthen or demolish.

The Act defines a hazardous building as one where the ultimate capacity of the structure is exceeded by earthquake forces half as great as those specified in the Model Building By-Law. To many, this would appear to say that the building could have just less than half the strength required today. This is not correct. In the design of new buildings, the ultimate strength design is gaining preference over the old working stress design basis, particularly in reinforced concrete. In the application of this method of design, factors of safety are used, and in the case of seismic design the factor is generally about 1.4. Section $301 \mathrm{~A}$ does not make any provision for such factor of safety so that the true comparative value of the seismic force is reduced from one half to about one-third. The scope of the Local Authority's powers is thus signficantly reduced from the first impressions and the number of buildings coming within this scope is doubtful. It is only on the overall stability of the structure that the writer considers these powers can be effectively used.

As mentioned previously, the local authority must now take the next step to determine whether the building should be secured or demolished. This is a complex matter and cases must be treated on individual merits. In general, strengthening of a building to bring it up to today's standards is usually uneconomic and there could be doubts about the structural behaviour of the strengthened building. In some cases, strengthening to reduce immediate hazards could be acceptable and so extend the economic life of the building. once an owner is advised of his building classification, it is likely that the pros and cons of strengthening or demolishing will be debated by his professional advisers and the local authority's engineer before the formal notice is issued.

Should the owner of a building in which a notice has been served wish to object, he may do so either to the council or the Courts for the matter to be determined. If the council reaffirms its requirement, confirmation of the notice is required by the courts. To date, there have been no applications to the courts on this matter.

Councils for a number of years, have been urging Government to give them powers to attack this problem of earthquake risk buildings. Now that this has been done in a limited way the responsibility lies with Councils. The initial step of a survey and classification will achieve a good return for the work involved. This is a formidable undertaking but vitally necessary. A major earthquake will give us the data without the survey but at an even more formidable price. Once the classification is known by owners, there will be an awareness of the position and a definite reaction. In many cases it is hoped owners will commence negotiations for planning and re-development.

The initial survey and its results provide the fundamental starting point for action by the local authority. With this information the Council knows the number of high earthquake risk buildings and the hazards involved. From this, several possibilities arise:-

\section{(1) Publicity:}

Owners should be advised of the results of the survey and the life evaluation of the building. It is hoped that this will initiate action for redevelopment and a sense of responsibility on the part of the owner. A side effect of the classification will result in the more realistic prices that will be paid when properties change hands. At the present time local authorities who have not carried out the survey will have some difficulty in assessing an individual building life when the overall picture is not available.

\section{(2) Insurance:}

Many owners will not react to the notice of classification by planning re-development, but will merely await notice of demolition or strengthening of the building, with the idea of contesting the authority. If a penal rate of insurance was applied because the building was a poor risk then an owner might be made more aware of the position and hasten the re-development programme. The Earthquake and War Damage Act 1944, was introduced as a compulsory levy on fire insurance to create a fund to offset losses caused by a major disaster. The liability of the Earthquake and War Damage Commission is restricted to the cost of replacement of the building to the state it was prior to earthquake provided that this does not exceed the sum insured. From the national point of view, the assets of the Earthquake and War Damage Commission are not great, and, although the fund is steadily increasing, New Zealand cannot afford to have a major disaster, let alone lose lives in the process.

Under the Act the Commission has powers to classify the building in relation to the earthquake resistance. Three categories are listed:-

Class A: Property with a good measure of resistance.

Class B: Property with a fair measure of resistance.

Class C: Property with little resistance.

To the writer's knowledge, this evaluation of buildings has not been done and unfortunately the Act states that "until the Commissioner has classified any property it shall be deemed to be classified in Class $A . "$

Now that we have a national classification system that can be used by all local authorities, it is suggested that the Earthquake and War Damage Commission look at the possibility of using Category $B$ and Category $C$, and applying penal rates for poorer structures. This would undoubtedly hasten demolition, protect the public, and assist the local authority 
iṇ many cases.

\section{(3) Compensation:}

Another avenue open to the insurance people could be by way of incentive to owners to demolish earthquake risk buildings. If owners of such buildings were offered a lump sum compensation by the Earthquake and War Damage Commission, owners could be tempted to take advantage of such a scheme. The amount of payment would have to be worked out on a probability basis by the Commission and a certain percentage could be budgeted for each year. Incentives such as this would see a continuing programme of removal of these high risk buildings. It must be remembered that the financial aspects are one field only and, although the collapse of a building in an earthquake is the concern of the owner, the possible loss of life is the major consideration.

\section{CONCLUSION:}

For a number of years local authorities pressed for legislation to deal with this problem. Now that this has been granted and a Code of Practice published, it is essential that progress be made in the classification of buildings as set out in that document. Once this is done and owners are advised of the position they, too, have a responsibility to the users of their building. One writer once suggested that the classification be displayed above the entrance to all buildings so that the public are aware of the position.

To hope that a mere classification will achieve the objective is wishful thinking and a positive attitude to the problem is required. The overall position within an area should firstly be obtained by means of the classification and then a realistic programme for demolition or strengthening evolved after detailed examination of each particular case. To avoid a national disaster from collapsed buildings, a programme to remove such hazards is necessary.

Government has delegated power to the local authorities to deal with buildings that are likely to be hazardous in the event of an earthquake. The public in general looks to the Local Authority to protect them by exercising these powers in a reasonable manner. Local body engineers have a reasponsibility both to the public and our Councils to accept the challenge and make progress in this matter.

Assistance by the Earthquake and War Damage Commission on an area or national basis of penal rates for insurance or compensation for demolishing buildings would reinforce the efforts of the local authorities and hasten the removal of earthquake risk buildings. 